\title{
WATER TRANSFER FROM SÃO FRANCISCO RIVER TO SEMIARID NORTHEAST OF BRAZIL: TECHNICAL DATA, ENVIRONMENTAL IMPACTS, SURVEY OF OPINION ABOUT THE AMOUNT TO BE TRANSFERRED
}

\author{
RUBISMAR STOLF ${ }^{1}$, SONIA M. DE S. PIEDADE ${ }^{2}$, JAIR R. DA SILVA ${ }^{3}$, LUIZ C. F. DA \\ SILVA ${ }^{1}$, MIGUEL Â. MANIERO ${ }^{1}$
}

\begin{abstract}
The transposition of the São Francisco River is considered one of the greatest engineering works in Brazil of all time since it will cross an extensive agricultural region of continental dimensions, involving environmental impacts, water, soil, irrigation, water payment and other multidisciplinary themes. Taking into account its importance, this subject was incorporated into a discipline of UFSCar (Federal University of São Carlos - Brazil) named "Pollution and Environmental Impacts". It was noted strong reaction against the project, even before the presentation. To allow a critical analysis, the first objective was to compile the main technical data and environmental impacts. The second objective was to detect the three most important aspects that cause reaction, concluding for the following reasons: assumption that the volume of water to be transferred was much greater than it actually is proposed in the project; lack of knowledge about similar project already done in Brazil; the idea that the artificial canal to be built was much broader than that proposed by the project. The participants" opinion about "volume to be transferred" was raised quantitatively four times: 2-undergraduate students; 1-graduate; 1-outside community. The average resulted 14 times larger than that proposed in the project, significant according to t-test. It was concluded that the reaction to water transfer project is due in part to the ignorance combined with a preconceived idea that tend to overestimate the magnitude of environmental impacts.
\end{abstract}

KEYWORDS: Integration, water transfer, volume, technical data, Northeast, semiarid.

\section{TRANSPOSIÇÃO DO RIO SÃO FRANCISCO PARA O NORDESTE SEMIÁRIDO DO BRASIL: DADDOS TÉCNICOS, IMPACTOS AMBIENTAIS E ENQUETE SOBRE O VOLUME TRANSPOSTO}

RESUMO: A transposição do Rio São Francisco, uma das maiores obras de engenharia do Brasil de todos os tempos, cortará uma extensa região agrícola de dimensões continentais, envolvendo temas de caráter multidisciplinar, como impactos ambientais, água, solo, irrigação, outorga de água e outros. Devido a sua importância, incorporou-se a partir de 2005 o tema a uma disciplina denominada Poluição e Impactos ambientais, UFSCar. Mesmo antes das apresentações verificava-se forte oposição. Preliminarmente, o objetivo do trabalho foi levantar os principais dados técnicos e impactos ambientais, culminando com uma análise crítica sobre a obra. $\mathrm{O}$ segundo objetivo constituiu-se em detectar no público participante das exposições os três aspectos mais relevantes que causavam oposição, concluindo-se pelas seguintes razões: a pressuposição de que o volume de água a ser transferido seria muito maior do que na realidade se propõe no projeto; o desconhecimento de outras obras de transposição em operação no Brasil e a ideia de que o canal artificial teria largura muito maior do que o proposto. Quanto ao item volume a ser transferido, levantaram-se quantitativamente os valores imaginados pelos participantes em quatro apresentações (cursos de graduação-2, curso de pós-graduação-1 e apresentação pública externa-1). Verificou-se diferença significativa entre o valor pressuposto e o real do projeto, segundo o teste $\mathrm{t}$, para cada levantamento, resultando média geral 14 vezes maior que o proposto. Concluiu-se que a reação à implantação do projeto, deve-se em parte, ao desconhecimento com tendência a superestimar a ordem de grandeza do impacto ambiental.

PALAVRAS-CHAVE: Integração, transferência de água, volume, dados técnicos, Nordeste, semiárido.

\footnotetext{
${ }^{1}$ Eng $^{\circ}$ Agrônomo, Prof. Dr., Universidade Federal de São Carlos (UFSCar), Dep. Recursos Naturais e Proteção Ambiental, Fone: (019) 35432616, rubismar@ cca.ufscar.br (www.cca.ufscar.br/drnpa/hprubismar.htm)

${ }^{2}$ Eng $^{\text {a }}$ Agrônoma, Profa. Dra., Universidade de São Paulo (Esalq - USP), Departamento de Ciências Exatas

${ }^{3} E^{\circ}{ }^{\circ}$ Agrônomo, Dr., Pesquisador, IAC, Centro de Engenharia, Jundiaí, SP

Recebido pelo Conselho Editorial em: 11-1-2011

Aprovado pelo Conselho Editorial em: 25-6-2012
} 


\section{INTRODUCTION}

According to MARENGO (2008) the Northeastern of Brazil tend to move from a semiarid to an arid zone, and the consequences of this change will affect the nutrition and health of the local population, there will be crisis in water supply for human consumption until 2025, regardless of the great work of transposition of the São Francisco River.

Thus, the transposition of the São Francisco River enters the future linked to climate change over the $21^{\text {st }}$ century, yet it is a recurring theme since the $19^{\text {th }}$ century, when, during the second empire, it was suggested the possibility of performing the work.

\section{From Dom Pedro II to Luis Inácio Lula da Silva: a portion of the history and polemic}

Two Brazilians distant in time, in training, in education, but united by the transposition of the São Francisco River, are opposites that are attracted by certain similarities.

Seventh son of Dom Pedro I, born on December $2^{\text {nd }}, 1825$, Dom Pedro II became heir to the throne on the death of his two older brothers, starting unusual life histories. Already motherless, he was left in Brazil by his father, D. Pedro I, at the age of 5, by interests of the Crown. Never again he saw his father. Living a great personal drama, with many indicating of an uncertain and gloomy future, took refuge in the Sciences, Arts, and Literature. Buoyed by his tutors, chosen by his own father, the boy "Pedrinho" showed extreme dedication to study and a great capacity for assimilation. Crowned Emperor of Brazil, became early, at 14 years old, the first ruler born in Brazil (except the regency) and only emperor born in the Americas. Contrary to the predictions of difficulties to remain in power, he ruled the country for a long period, until he was deposed on November $S$ $15^{\text {th }}$

1889, at the acme of its popularity. Nicknamed "the Magnanimous", detached from luxury, living in modest circumstances to a head of State, his long reign is recognized as the most press freedom, even compared to the republican regime (GONÇALVES \& ROSA, 2009; PEDRO II, 2011). According to LACOMBE (2003), he completed the unification of the country, performing numerous and extensive travel throughout the country, devoting himself to record by his own hand the events in detailed trip reports; there were also records of images (good drawer). The diary of one of his trips, held in 1859, through the Brazilian Northeast - Bahia, Sergipe and Alagoas - was transcribed verbatim in a book exceeding 300 pages, with footer comments of the compiler (LACOMBE 2003) using 43 books, deposited in the Imperial Museum (Petrópolis), referring to the journey for this time of difficult transport to an itinerant government with the participation of the Empress Teresa Cristina.

Had a special interest in education, involving himself personally in the matter. He devoted much of his time visiting schools and evaluating teaching in his travels. Lover of the Arts and Sciences, he had a school with 200 pupils and students in need with personal fund, apart from the Dom Pedro II School. His biggest frustration, he admits, was that the interest and efforts of the administration of the empire in education, combined with his personal example, found no echo in the provinces (GONÇALVES \& ROSA, 2009).

The President Luis Inácio Lula da Silva, son of a large family without resources, had to leave the semiarid, migrating to the industrialized state of São Paulo to try his luck in the difficult and extreme condition of migrant. Showing an unusual capacity to overcome obstacles, he also became one of the most influential men in our history (BOURNE, 2009).

Separated in time by a century and a half, opposites in education, the first, emperor of inheritance, the other, worker who became president; however, there are, between both, points in common: the obstacles of life, knowledge and interest in the semiarid Northeast, and specifically in transposition. From architect to builder, politically, Pedro II is the creator of the transposition of the São Francisco and Lula is the one who began to work effectively.

Between Pedro and Lula, many governments have tried (SILVA, 2011). However, the common thread that led to the study of the transposition is knowledge in loco of semiarid 
conditions. Lula, as is known to all, besides being born in the region, has undertaken reconnaissance trips to Brazilian Northeast. Likewise, D. Pedro II was, among several trips, specifically inspecting the actual effects of the severe drought of 1877-1879, witnessing the greatest catastrophe of any kind on record in South America: estimated half a million casualties.

Therefore, if in the political and technical perspective there are many conflicting opinions, it is quite understandable that the rulers, who lived on the spot a strong experience of the effects of a drought in the semiarid region, want, above all, to lead to the region the missing input, the water, in order to mitigate the effects of drought.

\section{Technical data of the transposition project of São Francisco River}

Figure 1 presents an overview of the transposition, in which São Francisco river itself is entirely included, in its original course, without allocating dams. Figure 2 details the work from taking water from São Francisco, and Table 1 contains the most relevant technical data of the project.

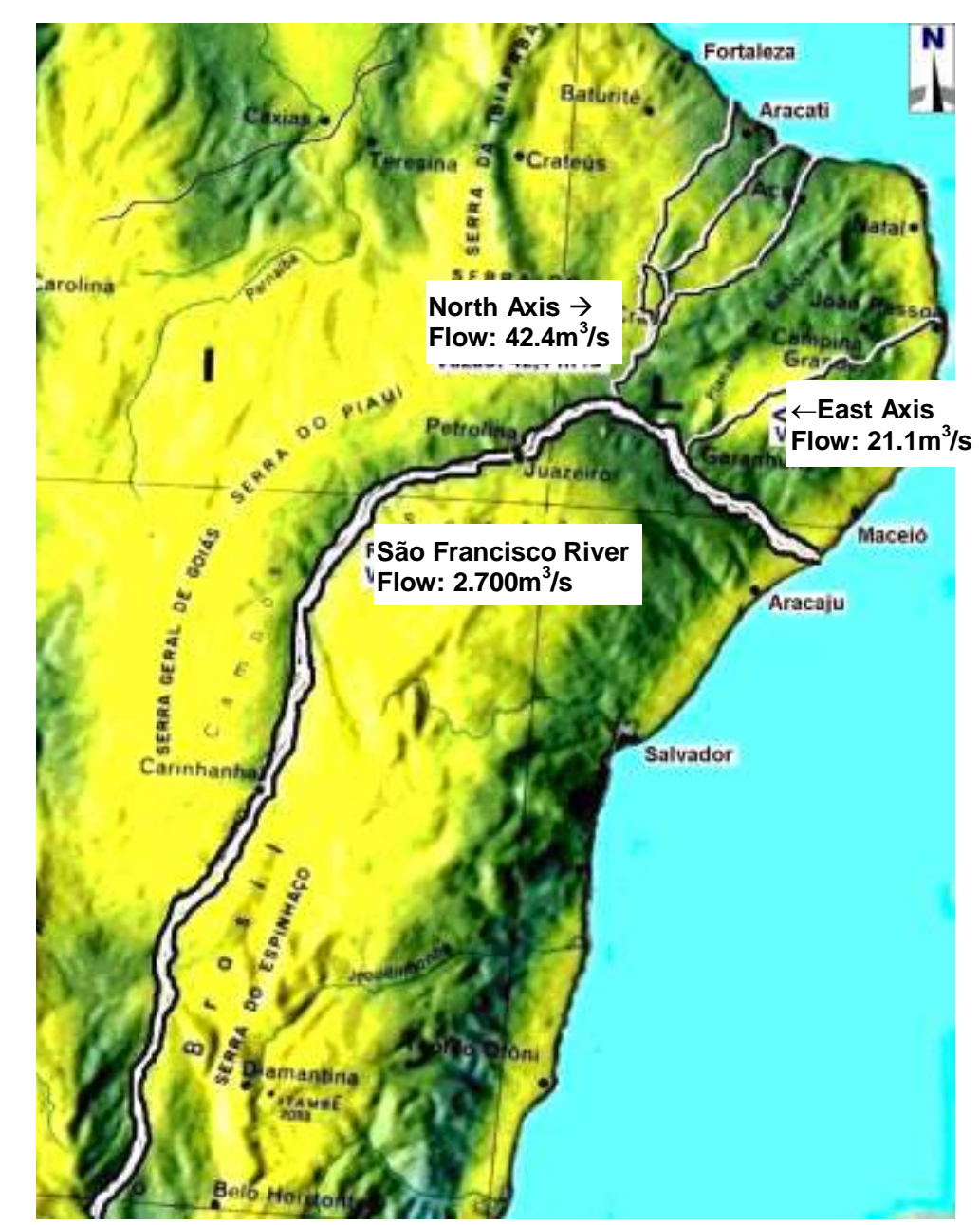

FIGURE 1. Overview of the project. Flows of São Francisco River and of the North and East axes (canals) of the transposition.

According to the project proposal (Figure 2), artificial canals (red lines), supplying nearby dams, follow in the semiarid northeast. Further, using natural canals, water will be transferred to the chutes of the region's rivers, perpetuating them. These receptor rivers follow on added water, blue dotted lines, until a large dam. After the aforementioned large dam, following, the river continues into the Atlantic Ocean (green dotted lines). Many large dams were built by DNOCS (ARAÚJO, 1982; STOLF, 1989). 


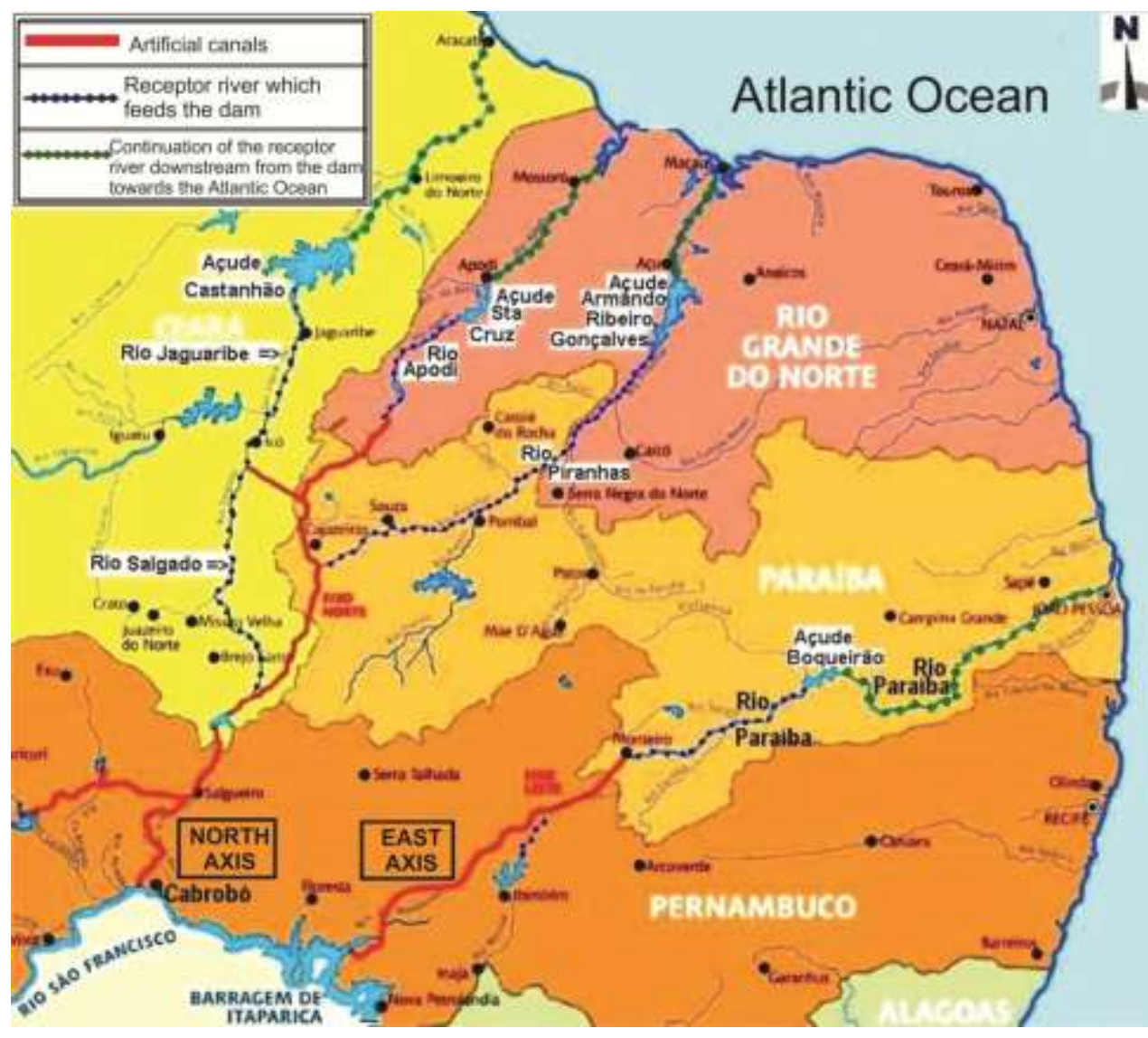

FIGURE 2. Transposition: route of water distribution at semiarid region.

TABLE 1. Main technical features of São Francisco River transposition.

- Mean flow of São Francisco River: $2.700 \mathrm{~m}^{3} / \mathrm{s}$

- Withdrawal mean flow proposed: $63.5 \mathrm{~m}^{3} / \mathrm{s}$ (water for transposition)

- North axis: 42.4 m³/s will be destined to the Jaguaribe, Apodi, and Piranhas Basins - Açu and Paraíba

- East axis: $21.1 \mathrm{~m}^{3} / \mathrm{s}$, to the State of Pernambuco, which shares the São Francisco Basin

- Annual volume thrown into the sea by Francisco River: 90 billion cubic meters

- Annual volume proposed for withdrawal: two billion cubic meters

- Total length of the São Francisco River: 2.800 km (passes through five states: Minas Gerais, Bahia/Pernambuco, Alagoas/Sergipe)

- Excerpt from São Francisco which will have reduction of flow: final $500 \mathrm{~km}$

- Total length of artificial canals to be build: $720 \mathrm{~km}$

- Total length of chutes of receptor rivers: $510 \mathrm{~km}$

- Overall total: $1.230 \mathrm{~km}$

- North axis: $402 \mathrm{~km}$ of artificial canals (4 pumping stations, 22 aqueducts, 6 tunnels e 26 small reservoirs). 360 $\mathrm{km}$ in river chutes

- East axis: $220 \mathrm{~km}$ of artificial canals e $160 \mathrm{~km}$ in river chutes

- Canals mean dimensions: Width: $25 \mathrm{~m}$; depth: $5 \mathrm{~m}$

- Work total cost: US\$ 4.5 billion (2004)

- Revitalization of the São Francisco River: US\$ 0.4 billion

- Variation of annual precipitation in the basin: $1.900 \mathrm{~mm}$ (source) - $400 \mathrm{~mm}$ (semiarid)

- Variation of annual evapotranspiration: $500 \mathrm{~mm}$ (source) - 2,200 mm (semiarid)

- Energy loss: $218 \mathrm{Mw}$. year (126 Mw.year that will no longer be produced due to reduction of river flow and 92 Mw.year that will be spent on pumping water). Obs.: independent study of LERNER (2006) indicates that losses vary proportionately with the flow demanded by transposition.

- Pumping unevenness: $160 \mathrm{~m}$ (corresponding to the difference in level between the riverside, in the city of Cabrobó, State of Pernambuco, and the apex of Chapada do Araripe, city of Jatí, state of Ceará)

- Beneficiary population: 12 million inhabitants ( city of São Paulo) 
For instance, in the east axis, an artificial canal of $220 \mathrm{~km}$ goes towards the Paraíba River. In Paraíba River, the waters will travel $80 \mathrm{~km}$ (blue dotted line), feeding a large dam: the Boqueirão. After the dam, the river flows to the sea near the city of João Pessoa. Along the way, there may be bifurcations to supply other dams, like the one of the city of Ibimirim (Poço da Cruz dam). This same pattern can be seen in the north axis (Figure 2).

According to Table 1, the mean flow of the São Francisco River is $2.700 \mathrm{~m}^{3} / \mathrm{s}$, while the withdrawal mean proposed is $63.5 \mathrm{~m}^{3} / \mathrm{s}$ (water for transposition), considering $42.4 \mathrm{~m}^{3} / \mathrm{s}$ for the north axis and $21.1 \mathrm{~m}^{3} / \mathrm{s}$ for the east axis.

This is a project of great magnitude which occurs in order to minimize the construction of canals and maximize the use of existing river chutes, reducing the cost of the work. The length of proposed artificial canals is $720 \mathrm{~km}$ (red lines), whereas the recovery of receptors river chutes is $510 \mathrm{~km}$ (blue dotted line), totaling $1.230 \mathrm{~km}$. If we consider that the transposition may also influence the flow after receiving waters in large dams (Castanhão, Santa Cruz, Armando Ribeiro Gonçalves and Boqueirão) the total course of implementation exceeds $2.000 \mathrm{~km}$ (sum of red, blue, and green lines in Figure 2 ).

\section{Environmental impacts and the systematic approach}

In the Environmental Impact Report, EIR (RIMA 2004), 44 environmental impacts were identified, including 23 considered as most relevant. From these impacts, 11 are positive and 12 are negative, to occur in planning and/or installation and/or operation phases (Table 2).

According to the law, mitigation measures for negative impacts and potentiating measures for positive impacts are described in EIR in relation to the 44 probable environmental impacts, as examples:

Example of a negative approach: item 14, Table 2, "Speculation in real state on the potentially irrigable plains in the vicinity of the canals". The implementation of the Project could result in increased demand for closest land and the most suitable for cultivation. This fact can lead to the exodus of small farmers (squatters, smallholder farmers and landless) and the sudden and exaggerated increase of the value of rural properties for sale, to raise the values of possible expropriation procedures, as for the subsequent resale of the occupied areas, or even to the productive use of the regions where the expected benefits become effective. Project proposal:

"Mitigation measures of the considered impact (item 14, Table 2, "Speculation in real estate on the potentially irrigable plains in the vicinity of the canals"): to promote regularization through discriminatory to be performed by the competent body; to register these rural areas, identifying and qualifying the buildings and their occupants; to expropriate areas."

Example of an approach of positive impact: item 20 of Table 2, "Dynamization of livestock activity and incorporation of new areas into the production process": The increase of water supply will allow: inclusion of new areas in irrigated agricultural perimeters; recovery of abandoned areas, for example, the project of irrigation of Poço da Cruz, in Ibimirim, state of Pernambuco (PE); insertion of areas along the canals to be constructed, as well as receptor rivers, named "diffuse irrigation"; and, finally, the inclusion of other areas that have potential for agricultural development in the semiarid region and are not producing due to lack of water. The total water to be transposed can facilitate, according to studies, approximately 161.500 ha, divided as follows: water for diffuse irrigation along the canals which will cater to 24.400 ha; water for planned irrigation which will cater to 137.100 hectares. This increase in irrigated areas resulting from the Project, in the Area of Influence, is approximately $78 \%$ of total irrigated area in 1995. Project proposal:

"Potentiating measures of the considered impact: (item 20 of Table 2, 'Dynamization of livestock activity and incorporation of new areas into the production process'): to accomplish the 'Program of Water Supply and Technical Support for Small Activities of Irrigation Along Canals 
for Agricultural Communities'; to develop environmental education activities and for proper use of water, aiming at the development without degradation of soil and water resources."

Thus, as required by licensing bodies, each impact, approached on the EIR, is technically presented in detail in the EIS (Environmental Impact Study). In total, the project includes 36 Basic Environmental Programs aimed at minimizing the environmental impacts of the construction of canals.

TABLE 2. Positive and negative environmental impacts according to the EIR, during the planning, installation and operation phases of the project.

\begin{tabular}{|c|c|c|c|c|c|}
\hline & $\begin{array}{l}+ \\
/\end{array}$ & POSITIVE OR NEGATIVE IMPACTS (+/-) & $\begin{array}{l}\text { PLAN. } \\
\text { PHASE }\end{array}$ & $\begin{array}{l}\text { INST. } \\
\text { PHASE }\end{array}$ & $\begin{array}{l}\text { OPER. } \\
\text { PHASE }\end{array}$ \\
\hline 01 & - & - Introduction of social tension and hazards during construction & $X$ & $X$ & \\
\hline 02 & - & - Rupture of socio-community relations during the construction phase & $\mathrm{X}$ & & \\
\hline 03 & - & Potential interference with indigenous populations & & $\mathrm{X}$ & $\mathrm{X}$ \\
\hline 04 & - & Risks of accidents involving the population & & $\mathrm{X}$ & \\
\hline 05 & - & Increase of dust emission & & $\bar{X}$ & $\mathrm{X}$ \\
\hline 06 & - & Increase and/or emergence of diseases & & $\mathrm{X}$ & $\mathrm{X}$ \\
\hline 07 & - & Increase of demand for health infrastructure & & $\mathrm{X}$ & \\
\hline 08 & - & Loss of potentially cultivable land & & $\mathrm{X}$ & \\
\hline 09 & - & - Temporary loss of Jobs and income due to expropriation & & $\bar{X}$ & \\
\hline 10 & - & Interference with areas of mining processes & $X$ & $\mathrm{X}$ & \\
\hline 11 & + & - Generation of Jobs and income during implementation & & $\mathrm{X}$ & \\
\hline 12 & + & •Dynamization of regional economy & & $\mathrm{X}$ & $\mathrm{X}$ \\
\hline 13 & - & Pressure on urban infrasctructure & & $\mathrm{X}$ & $\mathrm{X}$ \\
\hline 14 & - & Speculation in real state on the potentially irrigable plains in the vicinity of the canals & $\mathrm{X}$ & $\mathrm{X}$ & \\
\hline 15 & - & Risk of interference with the Cultural Heritage & & $\mathrm{X}$ & $\mathrm{X}$ \\
\hline 16 & + & Increase of water supply and warranty & & & $\mathrm{X}$ \\
\hline 17 & + & - Increase of water offer for urban supply & & & $\mathrm{X}$ \\
\hline 18 & + & 'Water supply for rural population & & & $\mathrm{X}$ \\
\hline 19 & + & Reduction of population exposure to drought emergencies & & & $\mathrm{X}$ \\
\hline 20 & + & $\begin{array}{l}\text { Dynamization of livestock activity and incorporation of new areas into the } \\
\text { production process }\end{array}$ & & & $\mathrm{X}$ \\
\hline 21 & + & Decrease of rural exodus and emigration from the region & & & $\mathrm{X}$ \\
\hline 22 & + & - Reduction of population exposure to diseases and deaths & & & $\mathrm{X}$ \\
\hline 23 & + & Reduction of pressure on the health infrasctructure & & & $\mathrm{X}$ \\
\hline 24 & - & $\begin{array}{l}\text { Loss and fragmentation of about } 430 \text { hectares of native vegetation and habitats of } \\
\text { terrestrial fauna }\end{array}$ & & $\mathrm{X}$ & $\mathrm{X}$ \\
\hline 25 & - & Decrease of diversity of terrestrial fauna & & $\mathrm{X}$ & $\mathrm{X}$ \\
\hline 26 & - & Increase of hunting with diminishing population of game species & & $\mathrm{X}$ & \\
\hline 27 & - & $\begin{array}{l}\text { Modification of the composition of the Native Aquatic Biological Communities of } \\
\text { receptor basins }\end{array}$ & & & $\mathrm{X}$ \\
\hline 28 & - & $\begin{array}{l}\text { Risk of biodiversity reduction of the Native Aquatic Biological Communities in the } \\
\text { receptor basins }\end{array}$ & & & $\mathrm{X}$ \\
\hline 29 & - & The impairment of biogeographical history knowledge of the Native aquatic groups & & & $\bar{X}$ \\
\hline 30 & - & - Risk of introduction of fish species potentially harmful to man in the receptor basins & & & $\mathrm{X}$ \\
\hline 31 & - & •Interference on fishing in receptor dams & & & $\mathrm{X}$ \\
\hline 32 & - & Risk of vectors proliferation & & & $\mathrm{X}$ \\
\hline 33 & - & Occurrence of accidents with venomous animals & & & $\mathrm{X}$ \\
\hline 34 & - & Instability of marginal slopes of water bodies & & & $\mathrm{X}$ \\
\hline 35 & - & Beginning/acceleration of erosion processes and entrainment of sediments & & $\mathrm{X}$ & \\
\hline 36 & - & Modification of fluvial regime of receptor drainages & & $\mathrm{X}$ & $\mathrm{X}$ \\
\hline 37 & - & Modification of the hydrosedimentological behavior of water bodies & & $\mathrm{X}$ & $\mathrm{X}$ \\
\hline 38 & - & Risk of eutrophication of new reservoirs & & $\mathrm{X}$ & $\mathrm{X}$ \\
\hline 39 & + & Improvement of water quality in receptor basins & & & $\mathrm{X}$ \\
\hline 40 & + & Increase of aquifer fluvial recharge & & $\mathrm{X}$ & $\mathrm{X}$ \\
\hline 41 & - & Beginning or acceleration of desetification processes & & & $\mathrm{X}$ \\
\hline 42 & - & Modification of fluvial regime of São Francisco River & & & $\bar{X}$ \\
\hline 43 & - & Reduction of electricity generation in São Francisco River & & & $\mathrm{X}$ \\
\hline 44 & - & Decrease in municipal revenue & & & $\mathrm{X}$ \\
\hline
\end{tabular}




\section{MATERIAL AND METHODS}

\section{Procedure to conduct the survey on the transposition}

a) Four presentations were made on the transposition for audiences of different profiles, in which the surveys were conducted:

Profile 1: (7 interviews): lecture at Municipal Library of Araras, 2007, public of diffuse profile.

Profile 2: (34 interviews): students of Agronomy of UFSCar, discipline: Soil Management, $3^{\text {rd }}$ year, $2^{\text {nd }}$ semester of 2005 .

Profile 3: (23 interviews): students of Agronomy and Agroecology of UFSCar, discipline: Pollution and Environmental Impacts, $1^{\text {st }}$ semester of 2009.

Profile 4: (7 interviews): students: Graduate in Agroecology and Rural Development, discipline: Pollution and Environmental Impacts, $2^{\text {nd }}$ semester of 2009.

b) Before every submission, we promoted a debate which, without exception, ended in a session of public criticism to the project. We tried to verify, then, if there was knowledge of the physical dimension of the work.

c) At the end of the preliminary discussion, the survey was realized with the following question:

\section{SURVEY ON THE PROJECT OF TRANSPOSITION OF SÃO FRANCISCO RIVER}

As explanation previously presented, the project constitutes, basically, in the use of part of the Sãd Francisco River to perpetuate rivers and dams in the Northeast during periods of drought, through the construction of two canals (North and East Axis). With this withdrawal, the flow of the São Francisco River will decrease.

In your opinion, what is the percentage of total loss of water, from the São Francisco River, foreseen in the project for the two canals?

d) The presentation of the lecture itself was realized.

\section{Statistical Analysis}

The mean of the survey of each profile was compared with the mean proposed in the project (2.4\%) by " $\mathrm{t}$ " test. The hypotheses were $\mathrm{H}_{\mathrm{o}}: \mu=2.4$ and $\mathrm{H}_{1}: \mu \neq 2.4$. The rejection of the hypothesis of equality at the level of $5 \%$ was indicated by the symbol (*); and of $1 \%$ by the symbol (**).

\section{RESULTS AND DISCUSSION}

\section{Survey Results}

In the preliminary discussion, preceding the survey, it was found that the three most important aspects that caused strong reaction from the public in relation to the work were:

- The assumption that the volume of water to be used in the transposition is much greater than it actually is proposed in the project.

- Lack of knowledge of great works of transposition in Brazil, as the supply of the metropolitan area of São Paulo (MASP). The transposed flow implemented in $2005,68.1 \mathrm{~m}^{3} / \mathrm{s}$ (HESPANHOL, 2008), surpassed the proposed in the project on the transposition of the São Francisco.

- The idea that the artificial canal to be built is much wider than the proposed one: hundreds of meters wide, compared to the $25 \mathrm{~m}$ of the project.

Among these, only the first was quantified through the survey, "transposed volume". As a result, all the surveys conducted in the respondents, on average, overestimated the volume of water 
to be transposed, with results statistically significant (Table 3). The overall average of surveys $(33.9 \%)$ resulted in 14 times greater than that proposed in the project $(2.4 \%)$.

TABLE 3 Survey: part of volume of the São Francisco River to be transferred according to those interviewed and according to the project (comparison by $t$ test).

\begin{tabular}{ccrrr}
\hline Public & Profile 1 & Profile 2 & Profile 3 & Profile 4 \\
\hline Mean & $14.0 \%(*)$ & $26.7 \%(* *)$ & $40.7 \%(* *)$ & $54.3 \%(* *)$
\end{tabular}

Overall mean of survey $=33.9 \%$

Mean proposed by the project $=2.4 \%$

$(*)$ : mean of the profile differs statistically from the mean proposed by the project, according to $t$ test at $5 \%$ probability; $(* *):$ at $1 \%$ probability; Profile 1: (7 interviews): lecture at Municipal Library of Araras, 2007, public of diffuse profile. Profile 2: (34 interviews): students of Agronomy of UFSCar, discipline: soil management, $3^{\text {rd }}$ year, $2^{\text {nd }}$ semester of 2005. Profile 3: (23 interviews): students of Agronomy and Agroecology of UFSCar, discipline: Pollution and Environmental Impacts, $1^{\text {st }}$ semester of 2009. Profile 4: (7 interviews): students: Graduate in Agroecology and Rural Development, discipline: Pollution and Environmental Impacts, $2^{\text {nd }}$ semester of 2009 .

Thus, the reaction to the implementation of the project is, in part, due to ignorance combined with a strong tendency to overestimate the magnitude of the withdrawal of water from the São Francisco River. With the presentation of the project itself, post-debate, there was a change of position or even a reduction of criticism of the work, compared to the preliminary discussion.

The difficulty of making a presentation on a controversial issue occurs because many of the present people do not accept to hear a presentation for a subsequent debate, but they manifested along with the presentation, featuring a controversial debate. Exemplifying: "The presentation of the Minister of National Integration, Ciro Gomes, during the first day of the $57^{\text {th }}$ Annual Meeting of the Brazilian Society for the Progress of Science (SBPC), has generated heated debate and political demonstrations. Among the audience, packed with students and researchers, demonstrators held bands contesting the possible benefits of the plan" (FUSARO, 2005). Another example: "Hundreds of protesters, including the Movement of Landless Workers, Indians and small producers are camped in Brasilia to press authorities to stop the work" (COLLIT, 2007). The methodology looked around this aspect.

\section{Critical comments on the project}

Numerous scientific articles promoting critical collaborations to the project reviewing the issue from various angles (AB'SABER, 2006; SIQUEIRA \& ZEELLHUBER, 2007; ALVES \& NASCIMENTO, 2009; SILVA, 2011). Others approach the subject in journalistic language for the attention aroused by society (FRANÇA, 2005). Another example, São Paulo Research Foundation (FAPESP), in its magazine, after getting an overview of criticism, both from the society and scientific environment, takes these issues to the project coordinator to answer, hearing arguments from both sides (IZIQUE, 2005). There are manifestations coming from the most diverse sectors, such as the National Conference of Bishops of Brazil (CNBB) (CAPPIO, 2008), politicians, such as former governor of Ceará State (ALCANTARA, 2006) and the, at the time, environment minister, Marina Silva, to the surprise of many, in favor of the project: "We are respecting Brazilian environmental legislation.... Our decision is not in favor of the government or of the movements. It is an absolutely technical decision on a licensing process passed with absolute impartiality and independence." (COLLIT, 2007).

In general, the criticism is directed to the following aspects: • Impact of withdrawal of water from the São Francisco River. • Favoring farms to the detriment of small farms. $\bullet$ Do not prioritize human supply. • Cistern alternative is more viable. $\bullet$ There is sufficient water reserve in dams in the northeast, what is lacking is a policy of allocating water through water mains. $\bullet$ There are groundwater reserves. • There is no water deficit in northern northeast: Ceará, Rio Grande do Norte, Paraíba. • Water should not be used for agribusiness. • The rainfall regime of the semiarid northeast coincides with the low-middle São Francisco (however, there is the positive aspect of 

noncoincidence in all other parts of São Francisco). • Simpler alternatives to solve the problem. The problem is not the lack of water, it is the unequal distribution of water resources.

Let us discuss the first criticism. Studies by the National Water Agency (ANA) for the Ten Year Plan of São Francisco river indicated a consumption of $91 \mathrm{~m}^{3} / \mathrm{s}(3.4 \%)$ in 2004 and a limit flow available for consumption of $380 \mathrm{~m}^{3} / \mathrm{s}$ (14.1\%) until 2013 (EIR, 2004). Therefore, the request for withdrawal of water for transposition, from the standpoint of environmental impacts $(2.4 \%)$, is within the permissible limit of withdrawal by ANA. Thereby, transposition only limits water use in the basin itself from $14.1 \%$ to $11.7 \%$. Thus, the papers criticize this aspect and not the environmental impact of water withdrawal, because, either way, this withdrawal had already been authorized, either in the transposition or in the future use of the basin itself. Therefore, the foundation of the technical discussion is whether some of the water from the São Francisco authorized for future use in the basin itself should or not be donated, in part, to the semiarid basins. As for the uninformed society, it is unaware that the impediment to project implementation will not prevent the consumption of water in other projects, and, more, imagine a massive withdrawal of water, a third of São Francisco, $915.3 \mathrm{~m}^{3} / \mathrm{s}$, corresponding to $33.9 \%$ much greater than the proposal (Figure 3). Therefore, the criticism of society and the scientific environment, apparently unison, are of different natures.

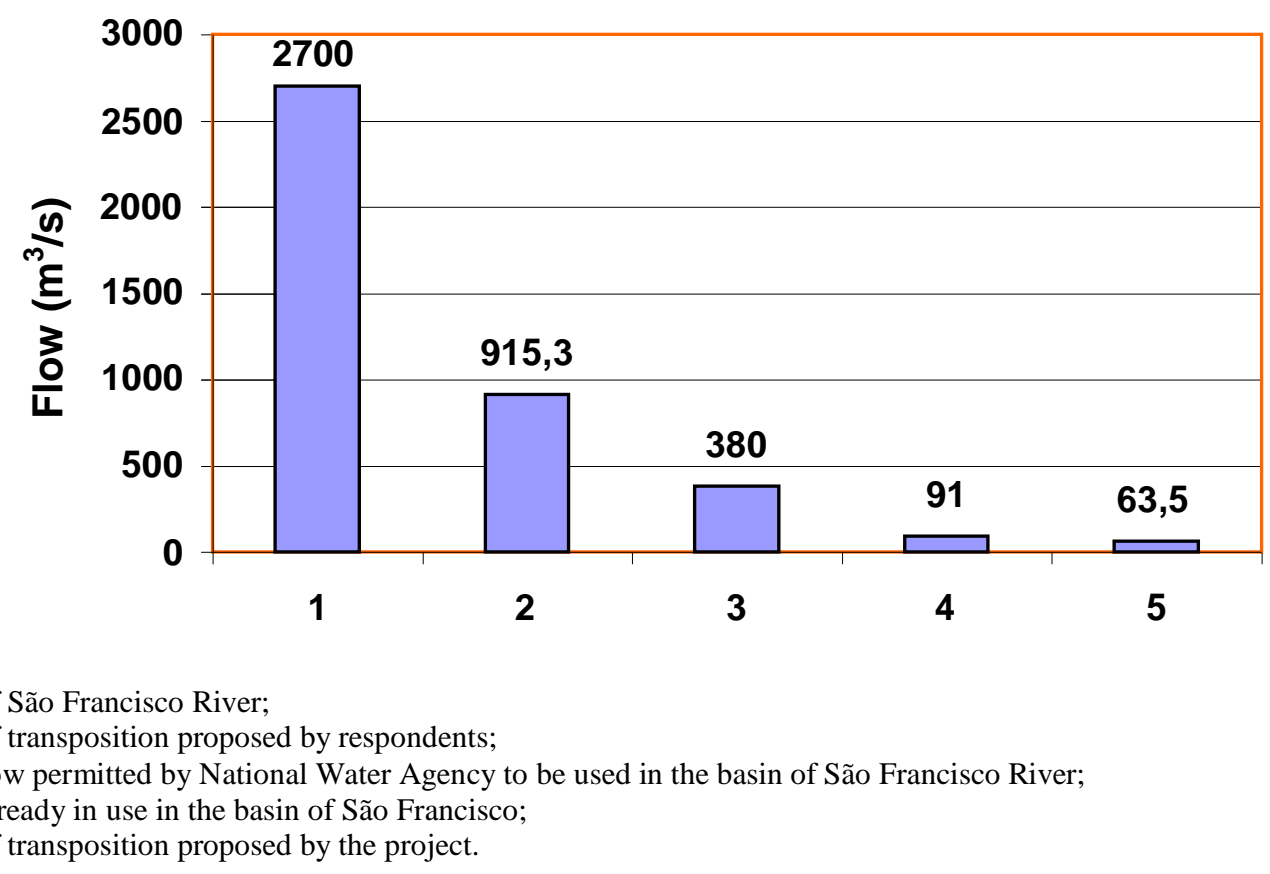

FIGURE 3. Withdrawal of water from the São Francisco River. Comparison of the flows.

Discussing the drought in semiarid regions, a water dam integrates the water events of its basin, several dams, from a region (STOLF, 1990). We shall take as an example of drought severity: Frei Jorge Stream, small intermittent course, belongs to the Riacho do Navio Basin which, in turn, is the main tributary of the Pajeú River. The Pajeú, located between the two axes of transposition, starts in Paraíba, in the border with the state of Pernambuco, cutting this last state before emptying into the São Francisco River, in the Itaparica dam, in the border with Bahia. When a river of this size, of a vast basin, drought, it settles a major drought in the basin. But, before this occurrence, most of its tributaries have already dried. The small dams located in their sub-basins, without recharging, start to suffer a steady reduction in volume due to evaporation. If the next recharging is insufficient to fill it so that it spills water through the weir surface, the mass of salt of the reservoir increases. Furthermore, smaller dams dry first (MELO \& PEREIRA, 2008). If this situation is prolonged in consecutive years, this phenomena can produce salinization of water which precludes its use (STOLF, 1977 and STOLF et al. 1979). Wen, for example, the 
Quebra-unhas dam, of the Frei Jorge Stream already dry, has a low volume, the soil and climatic conditions are unfavorable for its small basin of $64 \mathrm{~km}^{2}$. When the Pajeú river dries, it is an indicative of lack of water not only in its tributaries and low reserves in dams in the region, but it is also an indicative of unfavorable soil and climatic conditions in its vast basin of $17,000 \mathrm{~km}^{2}$, for food production and water supply for a population of about 400,000 inhabitants. MORRISON (2010) discussed the effects of social and agricultural drought in a semiarid municipality: "for families who survive on subsistence farming, reduced harvesting results in substantial reduction in available food supplies during the coming year."

On the other hand, in a region with precipitation of $1.200 \mathrm{~mm}$ per year, well distributed over nine months, there are perennial rivers and maintenance of large superficial water reserves. As if so many advantages were not enough, there are also water reserves in the soil to maintain crops with high productivity due to a positive soil water balance all year round. Therefore, there is still no technology that, besides maintaining perennial rivers and dams with reservations, promote water recharge in soil compartment throughout the basin, unless the rain itself. This is the great problem of semiarid Northeast: rainfall characterized by scarcity (500 to $800 \mathrm{~mm}$, with $400 \mathrm{~mm}$ spots), irregularity and unevenly distributed, concentrated in a period of about 3 months (MELO \& PEREIRA 2008; ALVES \& NASCIMENTO, 2009; SANTOS et al., 2009), causing partial or total loss of crop (PINHEIRO et al., 1996).

There will be no single solution to the "Polygon of droughts", one of the most populous and vast semiarid climate regions of the world $\left(1\right.$ million $\left.\mathrm{km}^{2}\right)$. There are a number of measures that have been adopted, to a greater or lesser degree, on the whole, to mitigate the problem: cisterns, barrages (dams), underground barrages in the dry river beds, water wells and groundwater, molecular films of high voltage to reduce evaporation, pipelines for water distribution, and others, and the transposition is one of them. For instance, the transposition is not a substitute for water collection

by cisterns and vice versa, yet they are complementary. If the construction of pipelines allows distribution of dam water, the guarantee of water in these dams, by transposition, multiply that possibility (ALCANTARA, 2006), especially considering that the perennial water courses will ensure the outlet water throughout the way. Therefore, it is not a matter to elect or dismiss a technique alone, since the joint use promotes a synergistic effect, complementary.

The negative environmental impacts in the receptor basins are important aspects to be considered (Table 2), however it is necessary to discuss its intensity. Without stating a fact that justifies another, many impacts are similar to those that occur in construction of highways: valuation of land, attractive to large companies, formation of large estates, evicting small farmers (impacts on the human environment); movement of large volumes of soil which alter the landscape (physical environment); spread of pests and diseases of wild species, introduction of exotic species, exposure of biomes near the roads (biotic environment). The glebes of the countryside, cut by national road network of 1.2 million $\mathrm{km}$, are exposed to all of these risks (EXTENSÃO, 2010). Thus, the striking effect is much higher compared to the construction of a narrow canal $(25 \mathrm{~m}), 720$ $\mathrm{km}$ long, to carry the most limiting input in the region and with all mitigating and/or compensatory projects to maintain the impacts under minimal intensity in order to maximize the positive balance in the calculation of impacts on the physical, biotic and anthropic environment. It is hoped that the involvement of a host of engineers, ecologists, biologists, geologists, anthropologists, and others professionals who are already moving to the construction site may contribute to the development of the region (PROJETO, 2009, RICHARD, 2009). After 150 years of indecision, mobilizing engineers, technicians, companies, consultants, the work began. At this stage, the many criticisms already promoted become important to guide the construction on track.

If we consider that the budget for preservation/restoration of the São Francisco basin is a political acceptance for the transposition (one of the criticisms of the project), is also a positive impact of the project and unprecedented for the type of investment. According to MACHADO (2008), the merits of the project was to introduce the idea of revitalizing watersheds in the role of public policy under the responsibility of the Union, States and municipalities. However the greatest 
positive impact of the project is to consolidate the greater movement in the history of Brazil in favor of a river. Using as a backdrop the transposition, regardless of the argument, it roses a big problem: the neglect of how we Brazilians have handled the São Francisco basin. It is a problem of environmental education, and not of transposition. We cannot forget that it is the tip of the "iceberg" of environmental damage that we are causing to our entire river network.

\section{CONCLUSIONS}

Restricted to the profile of respondents in four surveys conducted, it is concluded that the three most important aspects that cause strong public reaction were:

a) The assumption that the volume of water to be used in the transposition is much greater than it is actually proposed in the project (on average, 14 times higher).

b) Lack of knowledge of great works of transposition in Brazil, even in regions of relative abundance and good distribution of annual rainfall.

c) The idea that the artificial canal to be built is much wider than proposed: hundreds of meters wide, compared with the $25 \mathrm{~m}$ of the project.

\section{REFERENCES}

AB'SABER, Aziz. A transposição de águas do São Francisco: análise crítica. Revista USP, São Paulo, n.70, p. 6-13, ago. 2006.

BOURNE, R. Lula do Brasil a história real do Nordeste ao Planalto. São Paulo: Geração Editorial, 2009. 360p.

ALCANTARA, L. Um projeto para mudar o Brasil. Estudos Avançados, São Paulo, v.20, n.56, p. 293-300. 2006.

ALVES, J. J. A.; NASCIMENTO, S. S. Transposição do rio São Francisco: (des)caminhos para o semiárido do Nordeste brasileiro. Revista Espaço Acadêmico, Maringá, v. 9, n.99, p. 39-45, 2009.

ARAÚJO, J.A. (Coord.). Barragens no Nordeste Brasileiro: experiência do DNCS em barragens na região semi-árida. Fortaleza: dnocs, 1982. 160p.

CAPPIO, D.L.F.. Transposição das águas do Rio São Francisco. Estudos Avançados, São Paulo, São Paulo, v.22, n.63, p. 191-194. 2008.

COLLIT, R. Marina Silva defende transposição do rio São Francisco. Revista eletrônica Repórter Brasil, São Paulo, 14 mar. 2007. Available in: <

http://www.reporterbrasil.org.br/clipping.php?id=271>. Accessed in: 2 fev. 2011.

EXTENSÃO da malha rodoviária no Brasil. Available in:

<http://www.guiadotrc.com.br/infra/malharodoviariabrasileira.asp>. Accessed in: 4 fev. 2010.

FRANÇA, R. Veja, São Paulo, v. 38, n. 41, p.72-74, 12 out. 2005.

FUSARO, K. O sertão vai virar mar? Boletim Agência Fapesp, São Paulo, 17 jul. 2005. Available in: <http://www.agencia.fapesp.br/materia/4030/noticias/o-sertao-vai-virar-mar-.htm>. Accessed in: 19 jul. 2007.

GONÇALVES, R.; ROSA, R.L.A. D. Pedro II e o jornalista Koseritz. Rio de Janeiro, 2009. 341p.

HESPANHOL, I. Um novo paradigma para a gestão de recursos hídricos. Estudos Avançados, São Paulo, v.22, n.63, p. 131-158. 2008

IZIQUE, C. As águas vão rolar: transposição do rio São Francisco divide opiniões e instiga polêmica entre governo e pesquisadores. Pesquisa Fapesp, São Paulo, n. 112, p. 26-29, jun. 2005. 
LACOMBE, L.L.. Dom Pedro II: Viagens pelo Brasil: Bahia, Sergipe e Alagoas - 1859. Rio de Janeiro: Bom Texto, 2003. 338p

LERNER, G,L,S. Estudo de impactos na geração hidroelétrica ao longo do rio São Francisco devido à transposição de suas águas utilizando modelo matemático de fluxos em rede AcquaNet. 2006. 108 f. Dissertação (Mestrado em Engenharia - Ciências em Planejamento Energético) Universidade Federal do Rio de Janeiro, Rio de Janeiro, 2006.

MACHADO, A.T.M. A construção de um programa de revitalização na bacia do Rio São Francisco. Estudos Avançados, São Paulo, v.22, n.63, p. 195-210. 2008

MARENGO, J. A. Água e mudanças climáticas. Estudos Avançados, São Paulo, v.22, n.63, p. 8396. 2008

MELO, J. A. B.; PEREIRA, R. A. Recursos hídricos na zona rural do semiárido brasileiro: formas de captação, qualidade da água e configuração de cenários distintos. In: DANTAS NETO, J. (Org.). Uso eficiente da água: aspectos teóricos e práticos. Campina Grande, 2008. p. 40-63. Available in: <http://www.eumed.net/libros/2008c/447/ >. Accessed in: 14 dez. 2009.

PEDRO II, Imperador do Brasil. In Infopédia [Em linha]. Porto: Porto Editora, 2003-2011. [Consult. 2011-12-10]. Disponível em : <http://www.infopedia.pt/\$d.-pedro-ii-imperador-dobrasil>.

MORRISON, C. E. F.. A seca, o semiárido, e o pequeno agricultor em Canindé, Ceará. In:

TADDEI, R.; GAMBOGGI, A.L. Depois que a chuva não veio-Respostas sociais às secas na Amazônia, no Nordeste, e no Sul do Brasil. Rio de Janeiro: Fundação Cearense de Meteorologia e Recursos Hídricos, Instituto Comitas para Estudos Antropológicos, 2010, p.137-176.

PINHEIRO, U.; MACÊDO, A. P. B. A.; SOUSA, I. F. Precipitação esperada no semiárido do Rio Grande do Norte. In: CONGRESSO BRASILEIRO DE METEOROLOGIA, 9.,1996, Campos do Jordão. Anais..., Rio de Janeiro: Sociedade Brasileira de Meteorologia, 1996. p. 220-224, v. 1.

PROJETO São Francisco protege biodiversidade da caatinga. Em Questão, Brasília, n. 768, 16 fev. 2009. Available in: <http://www.jornallivre.com.br/318848/projeto-sao-francisco-protegebiodiversidade-da-caatinga.html>. Accessed in: 14 dez. 2010.

RICHARD, I. Obras do São Francisco criam mais de 8 mil empregos no sertão. 14 out. 2009. Agência Brasil - Portal de informação. Available in:

<http://www.pernambuco.com/ultimas/nota.asp?materia=20091014124016>. Accessed in: 2 nov. 2009.

RIMA - Relatório de Impacto sobre o Meio Ambiente do Projeto de integração do rio São Francisco com bacias hidrográficas do nordeste setentrional, Brasília, Ministério da Integração Nacional, 136p. Jun. 2004. Disponível em: < http://www.mi.gov.br/saofrancisco/integracao/rima.asp>. Acesso em: 10 ago. 2011.

SANTOS, M. J. ; ARAÚJO, L. E.; OLIVEIRA, E. M.; SILVA, B. B. Seca, precipitação e captação de água de chuva no semiárido de Sergipe. Engenharia Ambiental, Espírito Santo do Pinhal, v. 6, n. 1, p. 55-73, jan./abr. 2009.

SILVA, A.C.A.B. A transposição das águas do rio São Francisco: interesses e conflitos. In: CONGRESSO LUSO AFRO BRASILEIRO DE CIÊNCIAS SOCIAIS, 11, 2011, Salvador. Anais... Salvador: Universidade Federal da Bahia, 2011. CD-ROM.

SIQUEIRA, R. e ZEELLHUBER, A. Rio São Francisco em descaminho: degradação e revitalização. Cadernos do CEAS, Salvador, n.227, 34p. jul./set. 2007. Available in: < www.cptba.org.br/download/artigos/sf_em_descaminho_ceas.pdf $>$. Accessed in: 5 abr./set 2011. 
STOLF, R. Balanço de água e cloro no açude Quebra - Unhas (PE) utilizando as variações naturais de oxigênio-18, deutério e cloro. 1977.122 f. Dissertação (Mestrado) -Escola Superior de Agricultura Luiz de Queiroz, Universidade de São Paulo, Piracicaba, 1977.

STOLF, R. Monitoramento de recursos hídricos de bacias hidrográficas de vastas regiões através de açudes, utilizando aerofotogrametria: aplicação para o Nordeste brasileiro. In: CONGRESSO BRASILEIRO DE ENGENHARIA AGRÍCOLA, 19., 1990, Piracicaba. Anais... Piracicaba: Sociedade Brasileira de Engenharia Agrícola, 1990. p.281-293. v.1.

STOLF, R. Teste do modelo do cone invertido (STOLF, 1988) nos mais representativos açudes do Nordeste brasileiro para a determinação das curvas cota-volume e cota-área inundada. In: CONGRESSO BRASILEIRO DE ENGENHARIA AGRÍCOLA, 18., 1989, Recife. Anais... Recife: Sociedade Brasileira de Engenharia Agrícola, 1989. p.768-791.v.2.

STOLF, R., LEAL, J.M., FRITZ, P., SALATI, E. Water budget of a dam in the semi-arid Northeast of Brazil based on oxygen-18 and chlorine contents. In: ADVISORY GROUP MEETING ON THE APPLICATION OF NUCLEAR TECHNIQUES TO THE STUDY OF LAKE DYNAMICS, 1977, Vienna. Proceedings... Vienna: IAEA, 1979. p.57-66. 